\title{
TRADE BALANCE RESPONSE TO SHOCKS IN MONETARY POLICY AND EXCHANGE RATE: EVIDENCE FROM PAKISTAN USING SVECM APPROACH
}

\author{
Abdul Rahman Nizamani* \\ University of Sindh \\ Universiti Kebangsaan Malaysia \\ Zulkefly Abdul Karim \\ Universiti Kebangsaan Malaysia \\ Mohd Azlan Shah Zaidi \\ Universiti Kebangsaan Malaysia \\ Norlin Khalid \\ Universiti Kebangsaan Malaysia
}

\begin{abstract}
This paper examines the effects of monetary policy and exchange rate shocks on the trade balance of Pakistan. These effects are further investigated on the two broad categories of trade surplus and trade deficit sectors. This study has employed the Structural Vector Error Correction Model (SVECM) with a long run and short run restrictions to identify the monetary policy shocks. The results from the SVECM are consistent with the standard theoretical expectations i.e. free from empirical puzzles. The findings have revealed that the trade balance deteriorates to the contractionary monetary policy shocks, providing support to the expenditure switching effects of monetary policy in Pakistan. Furthermore, the effectiveness of monetary policy is only limited to trade surplus sectors. On the other hand, the exchange rate shocks do not support the J-Curve effects on both the aggregate as well as disaggregate level trade balance.
\end{abstract}

Keywords: Monetary Policy; Exchange Rate; Trade Balance; SVECM; Pakistan.

\section{INTRODUCTION}

The short run effects of the monetary policy on an economy have provided the leverage for policy makers to control the internal and external balance of a country. It is important for the policy makers to know the direction and the magnitude of the policy changes, so as to implement monetary policy as the stabilizing policy. The role of monetary policy in the emerging market economies is much highlighted due to the trade vulnerability in these economies. The small emerging economies are considered as the price receivers rather than price setters in the international market, in return these economies are prone to the adverse shocks. Therefore, the monetary policy is required to overlook the external position to maintain the competitiveness in international trade. There are two possible channels through which monetary policy influence the trade balance, the expenditure switching and the income channel.

*Corresponding author: Faculty of Economics \& Management, Universiti Kebangsaan Malaysia (UKM), 43600 Bangi, Selangor, Malaysia. Email: a.nizamani@usindh.edu.pk 
The monetary policy changes trigger both channel in opposite directions, and the variations in trade balance rely on the dominant channel between them (Kim 2001a, 2001b). Hence, for the effective monetary policy it is crucial to know the strength of expenditure switching and the income channel.

Pakistan as an emerging economy has been facing the dual challenge in internal and external balance. In order to tackle the internal balance as the primary objective, since 2005 the State Bank of Pakistan (SBP) has followed the tight monetary policy for nearly a decade to reduce the inflationary pressure on the economy. On the external balance, particularly in the current accounts, Pakistan has remained the trade deficit country since its inception. In recent years it has recorded the trade deficit of more than $10 \%$ of $\mathrm{GDP}^{1}$. In order to mitigate the trade deficit effects on the economy, the SBP has undertaken several attempts of currency devaluation in the past. More precisely, since 2007 the domestic currency has lost more than $50 \%$ of its value against U.S dollar. It is evident that SBP has been aggressively engaged in adjusting both the internal and external balances for Pakistan.

However, the tight monetary policy practices to adjust the internal balance of the country can have the implications on the external balance as well. The empirical evidence of the contractionary monetary policy effects on the internal balance suggests a strong consensus among monetary economists. Nevertheless, the evidence on the external balance, particularly on the trade balance has provided mix reaction. Malik (2007) have empirically shown that both internal and external balances play an important role to define the monetary policy stance in Pakistan. He proved that the deviations in trade balance and exchange rate significantly influence the monetary policy stance along with output and inflation rate. These stylized facts of monetary policy conduct raises concern that how does the monetary policy (contractionary) affect the trade balance in Pakistan? This study is aimed to answer this question. Furthermore, we also examine the underline effects on the disaggregated trade balance, this is in order disentangle the monetary policy effects on two broad categories of trade surplus and trade deficit sectors. Cantavella-Jordá \& Gutiérrez De Piñeres (2012) have argued that disaggregate analysis is essential for the close examination of monetary policy effects on the sectoral activity.

The present study contributes as following. First, this study has a direct contribution to the monetary policy committee of Pakistan, that whether the monetary policy (contractionary) improves the trade balance? The answer is going to address the effectiveness of monetary policy on the external balance. Second, the present study will bring out further evidence on the effects of the unexpected depreciation of exchange rates on the trade balance of Pakistan. It will provide the implications for the devaluation policy in the country. Third, the SVECM approach used in this study is in line with latest time series techniques to examine the dynamic interactions among macroeconomic variables. The SVECM allows the short run and long run restrictions to identify the monetary policy, and these restrictions are consistent with the monetary policy theory. Finally, this study extends the empirical evidence on the response of aggregate and disaggregated trade balance to the monetary policy (contractionary) shocks. The results from this study are consistent with the monetary policy theory. Specifically, we did not find any puzzle from the response of macroeconomic variables to the monetary policy shocks. The key finding from the results is that the monetary policy contraction does not improve the aggregate trade balance for Pakistan. Thus, we found the evidence in support to the expenditure switching effects of the monetary policy in Pakistan. Moreover, the effectiveness of monetary policy is only limited to the trade surplus sectors. Also, this study does not find the J-Curve effects on both the aggregate as well as disaggregate level trade balance from the real depreciation of exchange rates.

\footnotetext{
${ }^{1}$ Source: Pakistan bureau of statistics
} 
The rest of the paper is organized as follows. Section 2 provides the detailed literature review on the topic. Section 3 briefly discusses the SVECM methodology and the data. Section 4 presents the empirical results. Finally, the last section concludes the study.

\section{LITERATURE REVIEW}

The short run effects of the monetary policy on the macroeconomic variables are well documented in the literature. There is a strong consensus that the contractionary monetary policy exhibits negative effects on the macroeconomic variables of output and price level (See Cushman \& Zha (1997), Ramaswamy \& Sloek (1997), Christiano et al. (1999), Kim \& Roubini, (2000), and Elbourne \& Haan (2006)). Furthermore, the effects of contractionary monetary policy on the exchange rates of small open economies are well explained by the Dornbusch (1976) overshooting hypothesis. According to this hypothesis, the rise in interest rate representing the contractionary monetary policy will initially lead the appreciation in the real exchange rates, but as the economy adjusts to this shock the exchange rate will return to its depreciating path. Many empirical studies have favored this hypothesis, including Kim \& Roubini (2000), Mojon \& Peersman (2001), Linde (2003), Jang \& Ogaki (2004) and Peersman \& Smets (2005).

\subsection{Monetary Policy Effects on Trade Balance}

The effect of monetary policy on the external balance has been in the focus for recent years, particularly the effects on the trade balance. However, the previous literature provides the mix response from the trade balance to the monetary policy shock. For instance, Lee \& Chinn (1998) confirms that the temporary shock of monetary policy has positive effects on the trade balance in short run. Similarly, Prasad \& Gable (1997) reported the improvement in trade balance to the monetary expansions in industrial economies. Koray \& Mcmillin (1999) empirically analyzed the effects of contractionary monetary policy on U.S data, they found that monetary policy shock assert J-curve effects on the trade balance of U.S. Lane (2001) also finds the J-curve response of U.S trade balance to the monetary policy shock. In contrast, Kim (2001b) finds the negative effects on the trade balance of U.S owing to the monetary expansion shocks. However, Kim (2001a) reported the improvement in the trade balance of France, Italy and UK to the monetary expansion shock.

Kim (2001a, 2001b) argues that the monetary policy exerts two types of effects on the trade balance. One the income absorption effect and the other expenditure switching effect. For instance, the rise in interest rate corresponding to the contractionary monetary policy, on one hand, will limit the output level and hence decreases the income. In turn, it will lead the reduction in the import demand allowing improvement in the trade balance, which is known as income absorption effects. On the other side, the rise in the interest rate causes appreciation in exchange rates, which in turn increase the demand for foreign goods comparing to the domestic goods. Hence, it deteriorates the trade balance by reducing exports and increasing imports, known as expenditure switching effect. The response of trade balance depends on these two opposite effects. If an income absorption effect is stronger than expenditure switching effect, the trade balance will improve and if the expenditure switching effect is larger than income absorption effect, the trade balance will deteriorate.

Due to the recent methodological developments in analyzing the dynamic causal interactions of macroeconomic variables, like the SVECM which allows the theoretical understanding towards monetary policy shocks. Many studies are using SVECM to understand the effects of monetary policy 
shocks, for instance, recently Ivrendi \& Guloglu (2010) have analyzed the effects of contractionary monetary policy on the trade balance of five inflation targeting countries. They found that monetary policy contraction leads the improvement in the trade balance of Australia, Canada, New Zealand and Sweden, suggesting the dominance of income absorption effects in these countries. However, they found that the trade balance of U.K reacts negatively with the monetary policy shock. Ncube \& Ndou (2013) reports the dominance of expenditure switching effects in the trade balance of South Africa due to the contractionary monetary policy shocks. Similarly, Buyangerel \& Kim (2013) also found that monetary policy contraction leads the trade balance to worsen in the case of South Korea, giving support to the expenditure switching effects. Their findings are also based on SVECM approach.

\subsection{Exchange Rate effects on Trade Balance}

Apart from the monetary policy effects on the trade balance, the exchange rate variations pose substantial influence on the volume and variability of trade balance. The short run effects of exchange rate on the trade balance are explained by the J-curve hypothesis. This theoretical hypothesis, suggests that the depreciation in exchange rate initially deteriorates the trade balance, but gradually as the trade contracts adjust to the new exchange rates the depreciation will improve the trade balance in long run. However, the empirical work suggests that J-curve is not a regular phenomenon. For instance some studies found the evidence of J-curve effects on the trade balance (See Krugman \& Baldwin (1987), Bahmani-Oskooee (1992), Wilson (1993), Gomes \& Paz (2005), and Nadenichek (2006)) while others found mix results (See Haynes \& Stone (1982), Bahmani-Oskooee (1985), Marwah \& Klein (1996), Hsing (2005), Bahmani-oskooee \& Kutan (2009) and Kalyoncu et al, (2009)). On the other hand, a number of studies did not find the J-curve response of trade balance, studies including Rose \& Yellen (1989), Shirvani \& Wilbratte (1997), Upadhyaya \& Dhakal (1997), Baharumshah (2001), Ng et al. (2008), and recently Costamagna (2014). The J-curve effect depends on how immediately the export and import quantities adjust to the exchange rate changes if changes do not adjust then trade balance will not depict the J-curve response.

\subsection{Evidence from Pakistan}

Since we are interested in the behavior of Pakistan's trade balance to monetary policy and exchange rate shocks, it is imperative to report previous studies on Pakistan. Several studies have investigated the exchange rate effects on the trade balance of Pakistan. The previous studies dedicated to trace the Jcurve phenomenon in Pakistan have reported mix results. For example, Bahmani-Oskooee (1992), Aftab \& Aurangzeb (2002) and Rehman \& Afzal (2003) have reported the existence of J-curve effects on the trade balance of Pakistan. However, on the contrary, the recent literature did not find the J-curve effects (see Aftab \& Khan (2008), Bahmani-Oskooee \& Cheema (2009), Hameed \& Kanwal (2009) and Shahbaz (2009). Similarly, Shahbaz et al. (2012) carried out different tests to study the long run and short run effects of real exchange rates on the aggregate trade balance of Pakistan, they concluded that the devaluation policy will not improve the trade balance for Pakistan due to the absences of J-curve phenomenon.

To the best of our knowledge, no any attempts have been made pertaining to investigate the monetary policy effects on the trade balance of Pakistan. The present study aims to address such a gap by providing empirical evidence on the effects of contractionary monetary policy on the trade balance of Pakistan. 


\section{METHODOLOGY}

In order to study the dynamic response of trade balance to monetary policy and exchange rate shocks, we have employed the Structural Vector Error Correction Model (SVECM) developed by Breitung et al. (2004). Unlike the standard VECM, the SVECM allows the identification of structural shocks on the basis of economic theory. It separates the permanent and transitory shocks in the system by imposing long run and short run restrictions. As a result, it captures the meaningful dynamics of the variables. Assuming the economy is represented by the VAR $(\mathrm{P})$ process

$\mathrm{y}_{\mathrm{t}}=\mathrm{A}_{1} \mathrm{y}_{\mathrm{t}-1}+\mathrm{A}_{2} \mathrm{y}_{\mathrm{t}-2}+\cdots+\mathrm{A}_{\mathrm{p}} \mathrm{y}_{\mathrm{t}-\mathrm{p}}+\mu_{\mathrm{t}}$

Where $\mathrm{y}_{\mathrm{t}}$ is $(n \times 1)$ vector of endogenous variables, $A_{p}=\left(A_{1}, A_{2}, \ldots A_{p}\right)$ are parameter matrices, $\mu_{\mathrm{t}}$ is $(n \times 1)$ vector of unobservable error terms. If the variables in $y_{t}$ are cointegrated of order $r$ then the Structural-VECM can be written as

$$
\mathrm{B} \Delta \mathrm{y}_{\mathrm{t}}=\Pi^{*} \mathrm{y}_{\mathrm{t}-1}+\Gamma_{1}^{*} \Delta \mathrm{y}_{\mathrm{t}-1}+\cdots+\Gamma_{\mathrm{p}-1}^{*} \Delta \mathrm{y}_{\mathrm{t}-\mathrm{p}+1}+\varepsilon_{\mathrm{t}}
$$

Where $B$ is a contemporaneous matrix coefficient, $\Pi^{*}$ and $\Gamma^{*}$ are structural parameter matrices and $\varepsilon_{\mathrm{t}}$ is a $(n \times 1)$ structural form error with zero mean and covariance matrix $\Sigma_{\varepsilon}$.

Let matrix B an invertible matrix, then (2) will take the following form

$\Delta \mathrm{y}_{\mathrm{t}}=\Pi \mathrm{y}_{\mathrm{t}-1}+\Gamma_{1} \Delta \mathrm{y}_{\mathrm{t}-1}+\cdots+\Gamma_{\mathrm{p}-1} \Delta \mathrm{y}_{\mathrm{t}-\mathrm{p}+1}+\mu_{\mathrm{t}}$

Where $\Pi=\mathrm{B}^{-1} \Pi^{*}, \Gamma_{\mathrm{j}}=\mathrm{B}^{-1} \Gamma_{j}(j=1, \ldots p-1)$ and $\mu_{\mathrm{t}}=\mathrm{B}^{-1} \varepsilon_{\mathrm{t}} . \Pi$ has a reduced rank $(r \leq n-$ 1 ), and the matrix $\Pi$ can be factored as $\Pi=\alpha \beta^{\prime}$ where $\beta$ is as $(n \times r)$ matrix contains the long run relationship, $\alpha$ is a $(n \times r)$ matrix of speed of adjustment coefficient. The $\Gamma_{\mathrm{j}}$ are $(n \times n)$ matrices of structural form short run coefficients. The $\mu_{\mathrm{t}}$ is a white noise error with zero mean and covariance matrix $\Sigma_{\mu}$.

The impulse response functions are estimated by the relationship given below of structural form error $\left(\varepsilon_{t}\right)$ and reduced form errors $\left(\mu_{t}\right)$

$\mu_{\mathrm{t}}=\mathrm{B}^{-1} \varepsilon_{\mathrm{t}}$

$\Sigma_{\mu}=B^{-1} \Sigma_{\varepsilon}\left(B^{-1}\right)^{\prime}$

The relationship between structural form error $\left(\varepsilon_{t}\right)$ and reduced form errors $\left(\mu_{t}\right)$ in (4) is with correspondence to variance-covariance $\left(\Sigma_{\mu}, \Sigma_{\varepsilon}\right)$ matrices in (5). To identify the structural form parameters requires the imposition of $\left(n^{2}-n\right) / 2$ additional restrictions on the elements of $B^{-1}$. The traditional VAR imposes the Cholesky decomposition to identify the structural errors. However, the structural approach differs by the ability to choose any restrictions on $B^{-1}$ as to achieve the identification. Particularly, the structural approach is more relevant in the case of small open economies (Karim et al., 2012)

However, the existence of cointegration among the $I(1)$ variables could also provide extra identifying restrictions. That is, $y_{t}$ can be affected by two types of structural disturbances, one the disturbances from the permanent effects and the other from the transitory effects. 
According to the Granger's representation theorem (Johansen, 1995), the process $y_{t}$ has the following Vector Moving Average (VMA) representation².

$y_{t}=\Xi \sum_{i=1}^{t} \mu_{i}+\sum_{j=0}^{\infty} \Xi_{j}^{*} \mu_{t-j}+y_{0}$

Where, $y_{0}$ contains the initial values and $y_{t}$ consists the permanent and transitory shocks along with initial conditions. The matrix $\Xi=B_{\perp}\left[\alpha_{\perp}^{\prime}\left(I_{n}-\sum_{i=1}^{p-1} \Gamma_{i}\right) B_{\perp}\right]^{-1} \alpha_{\perp}^{\prime}$, the rank of $\Xi$ is given as $n-r$, where $r$ is the number of cointegrating vectors, thus there are $n-r$ independent common trend. Therefore $\Xi$ represents the long run effects of the permanent shocks. The second term in (6) is an infinite order polynomial with coefficient $\Xi_{j}^{*}$ approaching zero as $j$ tends to $\infty$, indicates the transitory shocks to the system.

Substituting (4) in (6) for $\mu_{t}$, the common trends term in (6) will give us

$\Xi \sum_{i=1}^{t} \mu_{i}=\Xi B^{-1} \sum_{i=1}^{t} \varepsilon_{i}$

Where, the long run effects are captured by $\Xi B^{-1}$ matrix which has the rank $n-r$ and $B^{-1}$ is a nonsingular matrix. Therefore, in a system with $r$ cointegrating relations, at most $r$ of the structural shocks will have transitory effects and at least $n-r$ of them will have permanent effects.

\subsection{Identification Scheme}

Given the reduced rank of the matrix $\Xi B^{-1}$ each column of zeros stands for only $n-r$ independent restrictions. Thus, if there are $r$ transitory shocks, the corresponding zeros represent $r(n-r)$ independent restrictions only. To identify the permanent shocks, $(n-r)[(n-r)-1] / 2$ additional restrictions are required to just-identify the system. Similarly, $r(r-1) / 2$ additional contemporaneous restrictions are required to identify the transitory shocks.

The long run impact matrix (8) and the contemporaneous restriction matrix (9) are given below for the following vector of endogenous variables $y_{t}=(T B I L L, L I P I D, L C P I D, L T B, L R E R)$. The detail description about variables in $y_{t}$ is provided in the section followed by.

$\Xi B^{-1}=\left[\begin{array}{lllll}0 & * & * & * & * \\ 0 & * & * & * & * \\ 0 & * & * & * & * \\ 0 & * & * & * & * \\ 0 & * & * & * & *\end{array}\right]$

The Johansen trace test has provided two cointegration relationships on $99 \%$ confidence band in $y_{t}$, but only one cointegration relationship is considered here. This is due to the fact that the, the monetary policy only causes a transitory effect on the macroeconomic variables and it does not affect other variables in the system, particularly in long run. So this theoretical inference has allowed us $r=1$ transitory shock on (8). The transitory shock is identified $r(r-1) / 2=0$ without any additional restrictions on $\mathrm{B}^{-1}$ in (9). Whereas, the $n-r=4$ permanent shocks require $(n-r)[(n-r)-1] /$ $2=6$ additional restrictions on $\Xi B^{-1}$ in (8) to just-identify the system. As the long run impact matrix (8) does not allow us more than 4 restrictions, that is theoretically we only allowed single transitory

${ }^{2}$ For details see Lutkepohl (2005) 
shock. According to Breitung et al. (2004) if theory does not accommodate enough restrictions on the long run impact matrix, then these restrictions can be imposed on the contemporaneous matrix (9). In total, $n(n-1) / 2=10$ restrictions were required but following Kim and Roubini (2000) we impose total of 12 restrictions to identify monetary policy shocks. The likelihood ratio (LR) test is used to validate the additional restrictions in the model. The probability value of 0.29 in Table A2 indicates that the additional restrictions are valid.

$$
\mathrm{B}^{-1} \varepsilon_{\mathrm{t}}=\left[\begin{array}{ccccc}
* & 0 & 0 & 0 & * \\
* & * & 0 & 0 & 0 \\
* & * & * & 0 & 0 \\
* & * & * & * & * \\
* & * & * & * & *
\end{array}\right]\left[\begin{array}{c}
\varepsilon_{T B I L L} \\
\varepsilon_{L I P I D} \\
\varepsilon_{L C P I D} \\
\varepsilon_{L T B} \\
\varepsilon_{L R E R}
\end{array}\right]
$$

The contemporaneous restrictions on (9), shows that the monetary policy in a row first does not respond to any variable except the exchange rate. This is because of low frequency data, which allows information delays. But we assume that monetary policy can respond to exchange rates by active intervention in the foreign exchange market to control its domestic currency. This is in line with the past practices of Pakistan's central bank (Khawaja, 2007 and Khan, 2010). The second and third rows show the goods market equilibrium condition where real output and price level contemporaneously responds to the interest rate. The fourth row belongs to the trade balance equation which contemporaneously responds to all variables in the system. The reasons for setting up the trade balance equation in this manner are twofold. One, the selected macroeconomic variables in our model are the key determinants of trade balance. Second, as our focal point is to study the trade balance response, so we let trade balance to interact with the system contemporaneously. The last row belongs to the real exchange rate. Since the exchange rate is the fast moving variable, we did not impose any further restriction on it. The system of equation in (9) is also influenced by the vector of exogenous variables $x_{t}=(L O I L, L I P I F, L C P I F)$, this is to control the adverse supply and productivity shocks from the external world.

\subsection{Data and Variables}

The data used in this study belong to a monthly frequency ranging from 2003:07 to 2015:12. All data have been gathered from IMF's international financial statistics except the trade balance data, which is collected from the State Bank of Pakistan (SBP). The data vector $y_{t}=$ (TBILL LIPID , LCPID , LTB , LRER) includes following variables. The short-term interest rate of sixmonth government treasury bill (TBILL) is used to represent the monetary policy stance in Pakistan. The industrial production index of Pakistan (LIPID) is used to proxy the real output and the consumer price index (LCPID) is used for price level. The exchange rate is represented by the real exchange rates (LRER), and it is calculated from the nominal exchange rates of domestic currency per U.S dollar by using the standard formula ${ }^{3}$. The choice of using the real exchange rate over the nominal exchange rate is because the trade balance theory explains the relationship with real instead the nominal exchange rates.

The trade balance (LTB) represents the aggregate trade balance of Pakistan in terms of the ratio between exports over imports. From most of the sample period undertaken, the trade balance of Pakistan has remained in deficit. Therefore, representing the trade balance in the ratio form allowed us to transform

\footnotetext{
${ }^{3}$ The U.S Consumer price index was used to represent the foreign prices in calculating the real exchange rate from the nominal exchange rate.
} 
the series into natural $\operatorname{logs}{ }^{4}$. We have further classified the aggregate trade balance into two groups ${ }^{5}$. One, the trade balance of those sectors that are trade surplus sectors (LTS) and particularly these sectors are net exporting sectors of Pakistan. Second, the trade balance of net importing sectors named as trade deficit sectors (LTD). The purpose of disaggregation of trade balance (LTB) into the trade balance of trade surplus (LTS) and trade deficit sectors (LTD) is to disentangle the monetary policy effects, owing to the fact that a price elasticity of demand for each trading sectors is different, whether in LTS or in LTD. For instance, the price elasticity of demand for manufacturing sectors would be different that of agriculture or mineral sectors. The trade surplus (LTS) and trade deficit (LTD) include several of such sectors and they might respond differently to monetary policy and exchange rate shocks. In our second and third SVECM models the vector $y_{t}$ is amended for (LTB) with (LTS) and (LTD) respectively.

In order to control the external shocks, we have used three exogenous variables $x_{t}=$ (LOIL , LIPIF , LCPIF). The oil prices (LOIL) are used to control for the adverse supply shocks. Whereas, the foreign output (LIPIF) and foreign price level (LCPIF) are used to control the productivity shocks. The U.S industrial production index and consumer price index are used to represent both the foreign output and price level.

All variables are transformed into natural logs except the short term interest rate which is kept in percentage. Furthermore, the seasonality of the data is adjusted by using the X-12 procedure.

\section{EMPIRICAL RESULTS}

It is pivotal to reveal the time series properties of the variables before analyzing the structural impulse response functions and variance decomposition. The Augmented Dicky Fuller (ADF) test for the existence of unit root has been reported in Table 1 . The test result shows that at variables are stationary at first difference. Hence, they are integrated of order one I(1). In order to perform the

Table 1: Augmented Dicky Fuller (ADF) Unit Root Test

\begin{tabular}{|c|c|c|c|c|}
\hline \multirow[b]{2}{*}{ Variables } & \multicolumn{2}{|r|}{ At levels } & \multicolumn{2}{|c|}{ At First difference } \\
\hline & Constant (AIC) & Constant \& Trend (AIC) & Constant (AIC) & Constant \& Trend (AIC) \\
\hline LIPIF & $-1.811(3)$ & $-1.879(3)$ & $-4.739 * * *(2)$ & $-4.727 * * *(2)$ \\
\hline LCPIF & $-2.204(2)$ & $-1.733(2)$ & $-7.660 * * *(1)$ & $-7.961 * * *(1)$ \\
\hline LOIL & $-2.539(2)$ & $-1.242(1)$ & $-8.842 * * *(0)$ & $-9.203 * * *(0)$ \\
\hline LIPID & $-2.816^{* *}(2)$ & $-3.058(2)$ & $-13.182 * * *(1)$ & $-13.289 * * *(1)$ \\
\hline LCPID & $-1.133(3)$ & $-0.668(3)$ & $-4.2077 * * *(2)$ & $-4.340 * * *(2)$ \\
\hline TBILL & $-2.327(12)$ & $-0.853(1)$ & $-3.609 * * *(11)$ & $-10.399 * * *(0)$ \\
\hline LTB & $0.318(5)$ & $-3.344 *(5)$ & $-8.252 * * *(4)$ & $-8.373 * * *(4)$ \\
\hline LTS & $-2.283(6)$ & $-1.123(5)$ & $-10.037 * * *(4)$ & $-9.990 * * *(4)$ \\
\hline LTD & $-2.379(2)$ & $-2.318(2)$ & $-6.680 * * *(7)$ & $-6.768 * * *(7)$ \\
\hline LRER & $-1.128(3)$ & $-3.086(5)$ & $-6.210 * * *(2)$ & $-6.191 * * *(2)$ \\
\hline
\end{tabular}

Note: The optimal numbers of lags are determined by Akaike information criterion (AIC). The Subscript **** indicates significant level at $1 \%$, ** at $5 \%$ and $*$ at $10 \%$ respectively. The null hypothesis for ADF test is that variable has a unit root. Critical value for null hypothesis for constant is $-3.515,-2.898$, and -2.586 at $1 \%, 5 \%$ and $10 \%$ significant level, and the critical value for constant and trend is $-4.073,-3.465$ and -3.159 at $1 \%, 5 \%$ and $10 \%$ significant level respectively.

\footnotetext{
${ }^{4}$ Similar approach has been used by Koray \& Mcmillin (1999), Singh (2002) and Ivrendi \& Guloglu (2010) to represent the trade balance as a ratio between exports over imports

${ }^{5}$ The SBP reports the trade data for 21 different trading sectors of Pakistan on HS-2 level. Among them 8 sectors are identified as net exporting (trade surplus) and remaining 13 as net importing (trade deficit) sectors.
} 
cointegration test, the lag length needs to be specified first. The optimal lag length selection criteria in Table A1 reports the lag length selected from different information criterion. We rely on Akaike Information Criterion (AIC) and Final Prediction Error (FPE) to choose the optimal lag length of three. To determine the number of cointegrating vectors in $y_{t}$, the Johansen trace test (Johansen, 1991), is reported in Table 2 . The test indicates that at $99 \%$ confidence band there are at most two cointegrating relationships in $y_{t}$. But we have chosen one cointegrating relationship for the theoretical reason provided in earlier section. The Figure A1 shows the stability of SVECM, the Tau statistics are smaller than the critical value of 5\% level in first panel, and the recursive Eigenvalue is also stable with $5 \%$ critical value in lower panel $^{6}$.

Table 2: Cointegration Test

\begin{tabular}{|c|c|c|c|c|c|}
\hline \multicolumn{6}{|c|}{$\begin{array}{l}\text { Johansen Trace Test for: TBILL, LIPID, LCPID, LTB, LRER } \\
\text { Included lags (levels): } 3\end{array}$} \\
\hline r0 & LR-statistics & P-value & $90 \%$ & $95 \%$ & $99 \%$ \\
\hline 0 & 125.12 & 0.0000 & 72.81 & 76.81 & 84.84 \\
\hline 1 & 64.43 & 0.0038 & 50.50 & 53.94 & 60.81 \\
\hline 2 & 38.61 & 0.0190 & 32.25 & 35.07 & 40.78 \\
\hline 3 & 16.27 & 0.1648 & 17.98 & 20.16 & 24.69 \\
\hline 4 & 7.19 & 0.1194 & 7.60 & 9.14 & 12.53 \\
\hline
\end{tabular}

Note: The r0 shows the number of cointegrating rank under the null hypothesis $\mathrm{Ho}, \mathrm{r} 0=0, \ldots, \mathrm{n}-1$.

\subsection{Structural Impulse Response Functions}

Figure 1 presents the impulse responses to a monetary policy and exchange rate shocks. The left and the middle column represents monetary policy shocks while the right-hand side column presents the impulses from the exchange rate shocks. Each response has a solid line in the middle represents the estimated response, whereas the two dashed lines are the confidence bands. These confidence bands represent Hall's bootstrapping method with $95 \%$ confidence interval and 3000 bootstrap replications.

Before tracing the response of trade balance to the monetary policy shocks, initially, we will analyze the response of other macroeconomic variables in the system. The left column shows the response of all macroeconomic variables except trade balance. The monetary policy shock is comprised of one percentage point increase in the short run interest rate, implying the contractionary monetary policy. The initial response of output to this shock is significantly negative and the response of price level is also negative. This is the expected response, as a rise in interest rate will reduce the aggregate demand in the country that in turn reduces output and price level. The last response in the left column shows that the exchange rate significantly goes down within the first quarter of the shock. The negative response implies the real appreciation in the exchange rates. The mean reversion of this response shows that the monetary policy effects are only significant in short run and the effects dissipate within two year horizon, this implies that real exchange rate returns to its historical trend after the initial shock. This response of exchange rate is consistent with the standard monetary theory that raise in interest rate appreciates the domestic currency relative to others. It is worth noticing that responses from these macroeconomic variables did not encounter any puzzle, whether it is an output puzzle, price puzzle or exchange rate puzzle. Hence, it ensures that our SVECM is well specified because puzzles often occur due to misspecified models in VAR framework (Sims, 1992).

\footnotetext{
${ }^{6}$ In order to carry out the robustness check the model is tested with different lag length and the results confirmed that impulse response functions generated with lag length 3 are stable.
} 


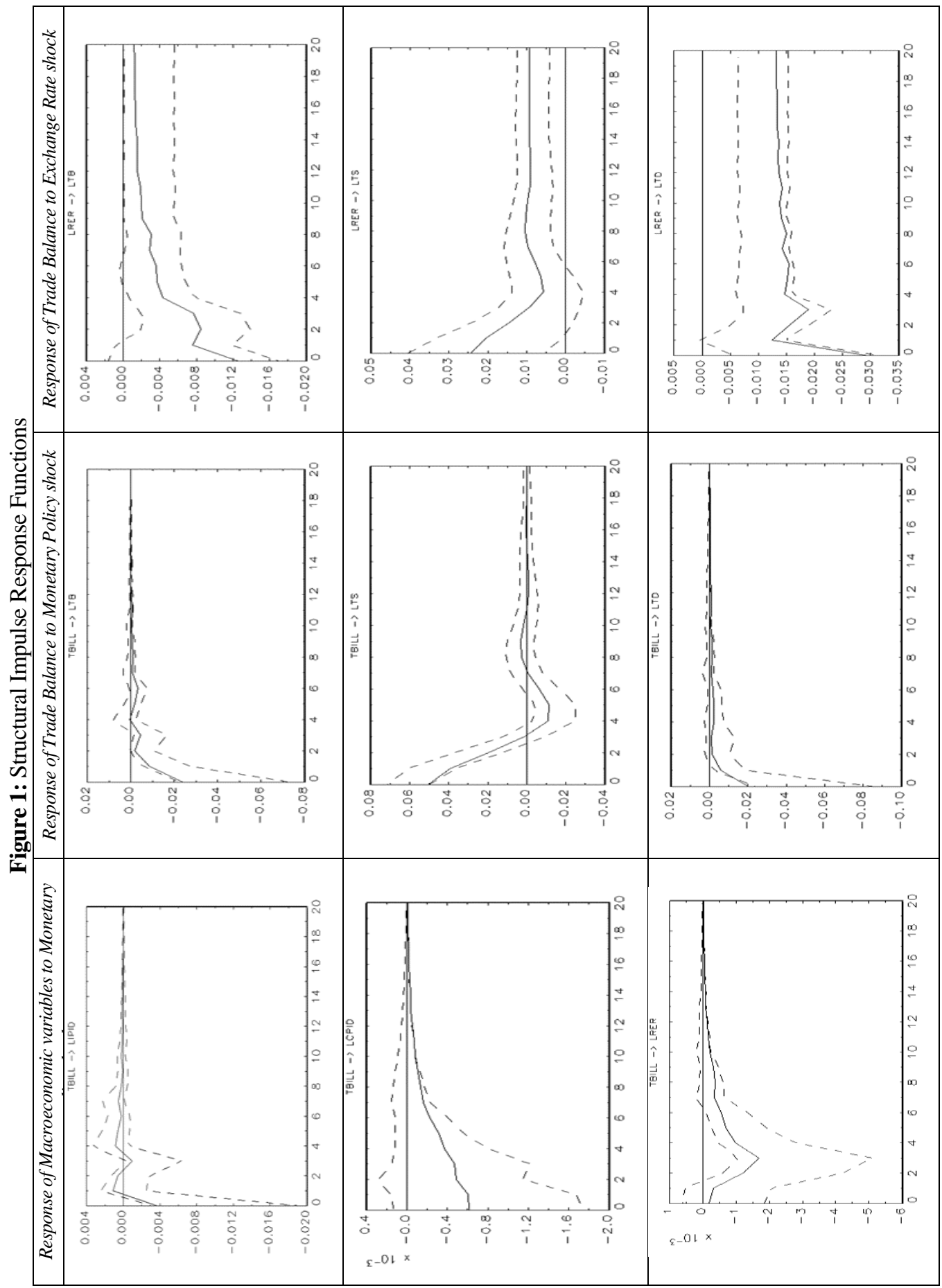


The middle column in Figure 1 shows the response of trade balance to the monetary policy shock. The first response belongs to the aggregate trade balance, corresponding to the one percentage point increase in the short term interest rate. This response is significantly negative to the contractionary monetary policy in a very short run and gradually dissipates. The initial impact of monetary policy shock accounts for $2 \%$ deterioration in the aggregate trade balance. Hence, it implies that expenditure switching effects are dominant than income effects on the trade balance of Pakistan. On the contrary, the response of trade surplus sectors is positive yet significant. The contractionary monetary policy records 5\% improvement in the trade balance of net exporting sectors. The dominance of income effects on these sectors suggests that the tight monetary policy effectively reduces the domestic income that in turn depresses the import demand. Thus, brings the improvement in the trade surplus sectors respectively. However, the response of trade deficit sectors in the bottom is similar to that of aggregate trade balance. This suggests that expenditure switching effects of the monetary policy shock dominates the income effect. One possible explanation for this response is that the real appreciation that is associated with the tight monetary policy leads the increase in import demands that in turn worse off their trade balance. The revealing feature of our finding is that in each of the three cases the response of trade balance to the monetary policy shock is not long-lasting, which is in line with the theoretical understanding that monetary policy causes temporary effects on the macroeconomic variables.

The right hand column shows the response of the trade balance to the real exchange rate shock. The shock to the exchange rate is associated with real depreciation in the exchange rates of local currency. The response of aggregate trade balance corresponding to the real depreciation is negative. Whereas, the response from the trade surplus sectors in the middle is positive. This reveals that the real depreciation improves the trade balance of net exporting sectors of Pakistan.

It is in contrast to the theoretically expected response of J-curve effects, which suggest that improvement in the trade balance is initially accompanied by deterioration in the short run. The improvement in trade surplus sectors shows that real depreciation increases the export competitiveness for local commodities in the global market relative to others. In the bottom, the response from trade deficit sectors is similar to the aggregate trade balance, showing the worsening of trade balance in net importing sectors. It implies that the trading sectors in trade deficit group in particular and overall trade in general are not capable of benefiting from the unexpected depreciation in the real exchange rate. That is due to the weak trade or export portfolio of Pakistan, which mainly comprises of agro based commodities. This is due to the fact that agro-based trade requires substantial time to respond to the sudden changes in exchange rates comparing to other trade e.g. manufacturing trade. In all these cases, we did not find the evidence of JCurve effect in Pakistan. However, the J-curve is not a regular phenomenon since many studies on the effects of exchange rate and trade balance have not traced it as well.

\subsection{Forecast Error Variance Decomposition}

The forecast error variance decomposition in Table 3 shows the relative contribution of the variables in the system. In order to conserve space, we only report the forecast error variance in the trade balance ${ }^{7}$ The top panel shows that the contribution from the monetary policy proves to be an important variable for the aggregate trade balance of Pakistan, which accounts $63 \%$ of the variation in the first period and gradually reduces to $23 \%$ along the horizon. The real exchange rate is also found to be the second important variable for the aggregate trade balance. For the trade surplus sectors in the middle, again the monetary policy shock dominates the attribution of $73 \%$ in the forecast error variance and followed by

\footnotetext{
${ }^{7}$ The forecast error variance decomposition for remaining variables are available upon request
} 
the real exchange rates. The fraction of the forecast error variance in the trade deficit sectors is leading with the real exchange rates accounting for $49 \%$ of variations followed by the monetary policy shock. Overall, the results from the forecast error variance decomposition show that the monetary policy of Pakistan has an important role in explaining the variations in the trade balance.

Table 3: Forecast Error Variance Decomposition of Trade Balance

\begin{tabular}{|c|c|c|c|c|c|}
\hline \multicolumn{6}{|c|}{ Proportions of forecast error in $L T B$} \\
\hline Steps & TBLLL & LIPID & LCPID & LTB & LRER \\
\hline 1 & 0.63 & 0.12 & 0.05 & 0.02 & 0.17 \\
\hline 4 & 0.44 & 0.12 & 0.14 & 0.07 & 0.23 \\
\hline 8 & 0.37 & 0.23 & 0.12 & 0.06 & 0.21 \\
\hline 12 & 0.31 & 0.33 & 0.11 & 0.07 & 0.19 \\
\hline 16 & 0.27 & 0.40 & 0.10 & 0.07 & 0.17 \\
\hline 20 & 0.23 & 0.45 & 0.10 & 0.07 & 0.15 \\
\hline \multicolumn{6}{|c|}{ Proportions of forecast error in LTS } \\
\hline Steps & TBILL & LIPID & LCPID & LTS & LRER \\
\hline 1 & 0.73 & 0.00 & 0.01 & 0.09 & 0.17 \\
\hline 4 & 0.64 & 0.07 & 0.01 & 0.10 & 0.18 \\
\hline 8 & 0.55 & 0.18 & 0.01 & 0.08 & 0.18 \\
\hline 12 & 0.49 & 0.23 & 0.01 & 0.08 & 0.19 \\
\hline 16 & 0.43 & 0.28 & 0.01 & 0.07 & 0.20 \\
\hline 20 & 0.39 & 0.32 & 0.01 & 0.06 & 0.21 \\
\hline \multicolumn{6}{|c|}{ Proportions of forecast error in LTD } \\
\hline Steps & TBLL & LIPID & LCPID & LTD & LRER \\
\hline 1 & 0.23 & 0.01 & 0.05 & 0.22 & 0.49 \\
\hline 4 & 0.16 & 0.03 & 0.06 & 0.15 & 0.60 \\
\hline 8 & 0.12 & 0.02 & 0.11 & 0.11 & 0.64 \\
\hline 12 & 0.09 & 0.02 & 0.17 & 0.09 & 0.64 \\
\hline 16 & 0.07 & 0.01 & 0.22 & 0.08 & 0.62 \\
\hline 20 & 0.06 & 0.01 & 0.26 & 0.07 & 0.60 \\
\hline
\end{tabular}

\section{CONCLUSION}

In this paper, we have analyzed the effects of monetary policy shock and the exchange rate shock on the trade balance of Pakistan, comprising both aggregate and disaggregate level data. The underline effects are captured through the structural impulse response functions estimated by SVEC models. The SVECM is identified with long run and short run restrictions along with exogenous variables to control the external supply and productivity shocks.

The results have revealed the following findings. First, the response of key macroeconomic variables are consistent with standard theoretical expectations, that is the contractionary monetary policy reduces the output level, decreases the price level and appreciates the exchange rate. Moreover, by imposing the long run restriction on the monetary policy and the short run contemporaneous restrictions based on the structural approach have led our results free from empirical puzzles. Second, the aggregate trade balance has responded negatively with the contractionary monetary policy shock, which implies that the expenditure switching effects are more dominant than the income effects on the trade balance of Pakistan. The trade balance of trade surplus sectors (net exporting sectors) has shown the positive response to the contractionary monetary policy shock. The dominance of income effect in trade surplus 
sectors proves that monetary policy is effective in the short run. However, the negative response of trade deficit sectors (net importing sectors) provides the predominant evidence of expenditure switching effects. Furthermore, the nature of responses from the trade balances is consistent with a theory in a way that monetary policy shock only carries out the temporary effects. Finally, the exchange rate shock associated with real depreciation did not improve the aggregate trade balance and the trade balance of deficit sectors. On the contrary, the trade surplus sectors showed improvement corresponding to the real depreciation in the exchange rates. However, we did not find the theoretical evidence for J-Curve effects on the trade balance of Pakistan.

The findings of this study suggest that the monetary policy leads significant effects on the trade balance of Pakistan in the short run along with other key macroeconomic variables. The effectiveness of monetary policy in Pakistan is only limited to the trade surplus sectors (net exporting sectors). However, this implication shall be taken cautiously as the monetary policy also asserts negative effects on the aggregate trade balance. The sudden depreciation in the real exchange rate shows that Pakistan's overall trading sectors are unable to benefit from this shock. Furthermore, it only benefits the trade surplus sectors (net exporting sectors) in short run. Hence, this suggests that stabilization policy in the exchange rate is preferable in the short run.

\section{REFERENCES}

Aftab, Z., \& Aurangzeb. (2002). The long-run and short-run impact of exchange rate devaluation on Pakistan's trade performance. Pakistan Development Review, 41(3), 277-286.

Aftab, Z., \& Khan, S. (2008). Bilateral J-Curves between Pakistan and Her Trading Partners. PIDE Working Papers 2008: 45.

Baharumshah, A. Z. (2001). The Effect of Exchange Rate on Bilateral Trade Balance : New Evidence from Malaysia and Thailand. Asian Economic Journal, 15(3), 291-312.

Bahmani-Oskooee, M. (1985). Devaluation and the J-Curve : Some Evidence from LDCs. The Review of Economics and Statistics, 67(3), 500-504.

Bahmani-Oskooee, M. (1992). More Evidence on the J Curve from LDCs. Journal of Policy Modeling, 14(5), 641-653.

Bahmani-Oskooee, M., \& Cheema, Je. (2009). Short-Run and Long-Run Effects of Currency Depreciation on the Bilateral Trade Balance Between Pakistan and Her Major Trading Partners. Journal of Economic Development, 34(1), 19-46.

Bahmani-oskooee, M., \& Kutan, A. M. (2009). The J-curve in the emerging economies of Eastern Europe. Applied Economics, 41(20), 2523-2532.

Breitung, J., Bruggemann, R., \& Lutkepohl, H. (2004). Structural Vector Autoregressive Modeling and Impulse Responses. In H. Lutkepohl \& , M. Kratzig (Eds.), Applied Time Series Econometrics (pp. 159-196). Cambridge: Cambridge University Press.

Buyangerel, B., \& Kim, W. J. (2013). The Effects of Macroeconomics Shocks on Exchange Rate and Trade Balances in Korea . Korea and the World Economy, 14(1), 91-119.

Cantavella-Jordá, M., \& Gutiérrez De Piñeres, S. A. (2012). A Cross-National Panel Study Of Devaluations On Disaggregated Export Sectors: A Case For Sector Specific PolicieS. Applied Econometrics and International Development, 12(2), 5-18.

Christiano, L. J., Eichenbaum, M., \& Evans, C. L. (1999). Monetary Policy Shocks : What Have We Learned and to What End? In J. B. Taylor \& M. Woodford (Eds.), Handbook of Macroeconomics (pp. 65-148). Amsterdam: Elsevier. 
Costamagna, R. (2014). Competitive devaluations and the trade balance in less developed countries : An empirical study of Latin American countries. Economic Analysis and Policy, 44(3), 266-278.

Cushman, D. O., \& Zha, T. (1997). Identifying monetary policy in a small open economy under flexible exchange rates. Journal of Monetary Economics, 39.

Dornbusch, R. (1976). Expectations and Exchange Rate Dynamics. Journal of Political Economy, 84(6), 1161-1176.

Elbourne, A., \& Haan, J. de. (2006). Financial structure and monetary policy transmission in transition countries. Journal of Comparative Economics, 34(1), 1-23.

Gomes, F. A. R., \& Paz, L. S. (2005). Can real exchange rate devaluation improve the trade balance? The 1990 - 1998 Brazilian case. Applied Economics Letters, 12(9), 525-528.

Hameed, A., \& Kanwal, S. (2009). Existence of a J-Curve -The case of Pakistan. Journal of Economic Cooperation and Development, 30(2), 75-98.

Haynes, S. E., \& Stone, J. A. (1982). Impact of the Terms of Trade on The U.S. Trade Balance: A Reexamination. The Review of Economics and Statistics, 64(4), 702-706.

Hsing, H.-M. (2005). Re-examination of J-curve effect for Japan , Korea and Taiwan. Japan and the World Economy, 17(1), 43-58.

Ivrendi, M., \& Guloglu, B. (2010). Monetary shocks, exchange rates and trade balances: Evidence from inflation targeting countries. Economic Modelling, 27(5), 1144-1155.

Jang, K., \& Ogaki, M. (2004). The effects of monetary policy shocks on exchange rates : A structural vector error correction model approach. Journal of The Japanese and International Economies, 18(1), 99-114.

Johansen, S. (1991). Estimation and Hypothesis Testing of Cointegration Vectors in Gaussian Vector Autoregressive Models. Econometrcia, 59(6), 1551-1580.

Johansen, S. (1995). Likelihood-Based Inference in Cointegrated Vector Autoregressive Models. Oxford: Oxford University Press.

Kalyoncu, H., Ozturk, I., Artan, S., \& Kalyoncu, K. (2009). Devaluation and trade balance in Latin American countries . Zbornik Radova Ekonomskog Fakulteta U Rijeci, 27(1), 115-128.

Karim, Z. A., Karim, B. A., \& Zaidi, M. A. S. (2012). Fixed Investment, Household Consumption, and Economic Growth: A Structural Vector Error Correction Model (SVECM) Study of Malaysia. International Journal of Business and Society, 13(1), 63-76.

Khan, I. N. (2010). Exchange Market Pressure Index in Pakistan. State Bank of Pakistan Working Paper Series N0.35.

Khawaja, M. I. (2007). Exchange Market Pressure and Monetary Policy : Evidence from Pakistan. The Lahore Journal of Economics, 12(2), 83-114.

Kim, S. (2001a). Effects of monetary policy shocks on the trade balance in small open European countries. Economics Letters, 71(2), 197-203.

Kim, S. (2001b). International transmission of U . S . monetary policy shocks : Evidence from VAR's. Journal of Monetary Economics, 48(2), 339-372.

Kim, S., \& Roubini, N. (2000). Exchange rate anomalies in the industrial countries : A solution with a structural VAR approach. Journal of Monetary Economics, 45(3), 561-586.

Koray, F., \& Mcmillin, W. D. (1999). Monetary shocks, the exchange rate , and the trade balance. Journal of International Money and Finance, 18(6), 925-940.

Krugman, P. R., \& Baldwin, R. E. (1987). The Trade Persistence of the U.S. Trade Deficit. Brookings Papers on Economic Activity, 18(1), 1-56.

Lane, P. R. (2001). Money Shocks and the Current Account. In G. A. Calvo, R. Dornbusch \& M. Obstfeld (Eds.), Money, Capital Mobility and Trade (pp. 385-411). Cambridge, MA: MIT Press.

Lee, J., \& Chinn, M. (1998). The Current Account and the Real Exchnage Rate: A Structural VAR Analysis of Major Currencies. National Bureau of Economic Research Working Paper No. 6495. 
Linde, J. (2003). Monetary Policy Shocks and Business Cycle Fluctuations in a Small Open Economy: Sweden 1986-2002. Sveriges Riksbank Working Paper Series No.153.

Lutkepohl, H. (2005). Structural Vector Autoregressive Analysis for Cointegrated Variables. European University Institute Working Paper, ECO No.2005/2.

Malik, W. S. (2007). Monetary Policy Objectives in Pakistan: An Empirical Investigation. PIDE Working Papers No. 35.

Marwah, K., \& Klein, L. (1996). Estimation of J-curves : United States and Canada. The Canadian Journal of Economics, 29(3), 523-539.

Mojon, B., \& Peersman, G. (2001). A VAR Description of the Effects of Monetary policy in the Individual Countries of the Euro Area. European Central Bank, Working Paper No. 92.

Nadenichek, J. (2006). The J-curve Effect : An Examination Using a Structural Vector Error Correction Model. International Journal of Applied Economics, 3(March), 34-47.

Ncube, M., \& Ndou, E. (2013). Monetary Policy and Exchange Rate Shocks on South African Trade Balance. African Development Bank Group Working Paper Series No. 169.

Ng, Y-L., Har, W-M., \& Tan, G-M. (2008). Real Exchange Rate and Trade Balance Relationship : An Empirical Study on Malaysia. International Journal of Business and Managment, 3(8), 130-137.

Peersman, G., \& Smets, F. (2005). The Industry Effects of Monetary Policy in the Euro Area. The Economic Journal, 115(503), 319-342.

Prasad, E. S., \& Gable, J. A. (1997). International Evidence on the Determinants of Trade Dynamics. IMF Working Papers WP/97/172.

Ramaswamy, R., \& Sloek, T. (1997). The Real Effects of Monetary Policy in the European Union: What Are the Differences? IMF Staff Papers, 45(2), 374-399.

Rehman, H. ur, \& Afzal, M. (2003). The J Curve Phenomenon: An Evidence From Pakistan. Pakistan Economic and Social Review, 41(1), 45-58.

Rose, A. K., \& Yellen, J. L. (1989). Is There A J-Curve. Journal of Monetary Economics, 24(1), 53-68.

Shahbaz, M. (2009). On Nominal and Real Devaluations Relation: An Econometric Evidence for Pakistan. International Journal of Applied Econometrics and Quatitative Estudies, 9(1), 85-108.

Shahbaz, M., Jalil, A., \& Islam, F. (2012). Real Exchange Rate Changes and the Trade Balance: The Evidence from Pakistan. The International Trade Journal, 26(2), 139-153.

Shirvani, H., \& Wilbratte, B. (1997). The Relationship Between The Real Exchange Rate and The Trade Balance : An Empirical Reassessment. International Economic Journal, 11(1), 39-50.

Sims, C. A. (1992). Interpreting the Macroeconomic Time Series Facts. The Effects of Monetary Policy. European Economic Review, 36(5), 975-1011.

Singh, T. (2002). India's trade balance: the role of income and exchange rates. Journal of Poli, 24(1036), 437-452.

Upadhyaya, K. P., \& Dhakal, D. (1997). Devaluation and the trade balance : estimating the long run effect. Applied Economics Letters, 4(6), 343-345.

Wilson, W. T. (1993). J-curve effect and exchange rate pass-through : an empirical investigation of the united states. The International Trade Journal, 7(4), 463-483.

\section{APPENDICES}

Table A1: Optimal Lag Length

\begin{tabular}{cccc}
\hline \hline \multicolumn{2}{l}{ Optimal number of lags (searched up to 12 lags) } & & \\
\hline Akaike Info Criterion & Final Prediction Error & Hannan-Quinn Criterion & Schwarz Criterion \\
\hline 3 & 3 & 1 & 0 \\
\hline \hline
\end{tabular}

Note: Endogenous variables includes: TBILL, LIPID, LCPID, LTB, LRER. Deterministic variable: Constant 

Using SVECM Approach

Table A2: SVECM Estimation

\section{Log Likelihood} 2609.6082
LR test: $\mathbf{X}^{\mathbf{2}}(\mathbf{2})$

2.4142
Probability

0.2991

Note: SVECM is over-identified with 2 degrees of freedom.

Figure A1: Stability of SVECM
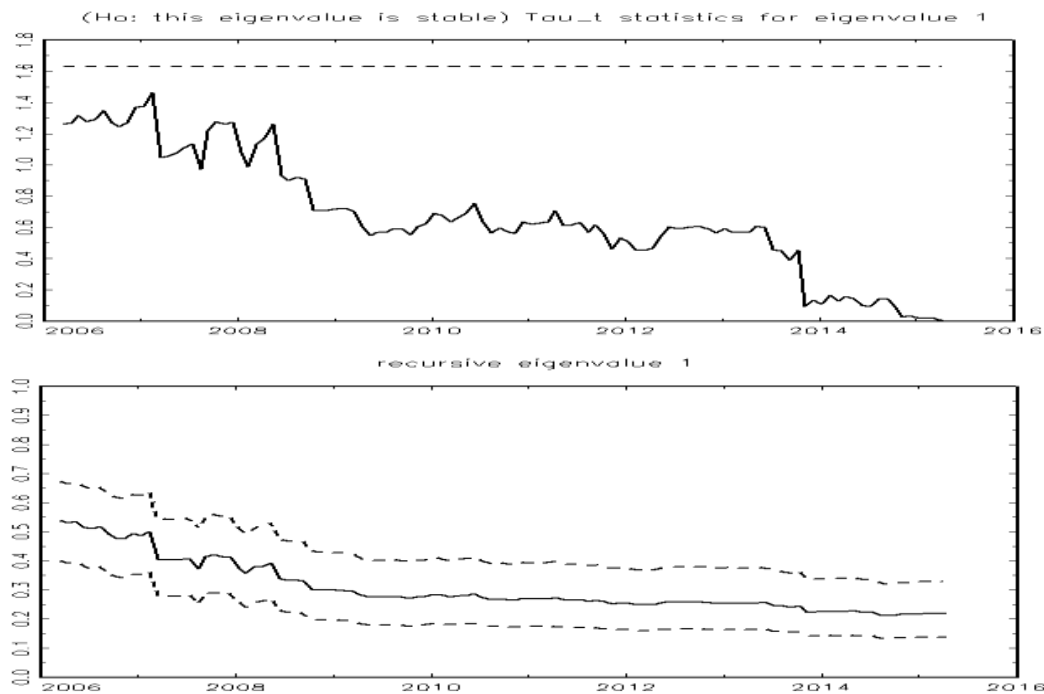